\title{
From Patent Counting Towards the System of IP Strategic Indicators
}

\author{
Tonis Mets', Aleksei Kelli², Ave Mets², Tiit Tiimann² \\ ${ }^{1}$ Queensland University of Technology \\ 2 George St GPO Box 2434, Brisbane, Qld 4001, Australia \\ E-mail.mets.tonis@gmail.com \\ ${ }^{2}$ University of Tartu \\ Ulikooli 18, 50090 Tartu, Estonia \\ E-mail.aleksei.kelli@ut.ee,ave.mets@ut.ee,tiimann.tiit@gmail.com
}

cross'ref $^{\text {http://dx.doi.org/10.5755/j01.ee.27.3.13799 }}$

The strategies of the European Union and its Member States suppose that intellectual property (IP) created as a result of $R \& D$ is the engine of economic growth and welfare in society. Studies based on the European Regional Innovation Scoreboard (RIS) have demonstrated that $R \& D$ investments, support to the high technology industry and patenting intensity of the public sector differ in high-and low-income European countries. This fact refers to the need for adequate IP strategic indicators' system facilitating innovation in less developed countries.

The paper aims to conceptualize and suggest a strategic indicators' system of IP for a small efficiency-driven economy. In contrast to the rather modest level of patenting by industry, universities of the Baltic States file approximately $50 \%$ of PCT patent applications. Therefore, it is crucial to overcome barriers, hindering universities' IP commercialization. Academia-Industry collaboration includes two types of IP strategies: Active non-linear and Passive linear behavioural models of universities and public sector. An essential part of the active approach focuses on the "soft measures" for networking with firms in collaborative platforms such as AIMday® at the Uppsala University in Sweden. The proposed IP strategy system involves qualitative and quantitative indicators at the state as well as university and company level. The comparison of academic publishing and patenting by the staff of Tartu and Uppsala universities testifies to their rather same levels of productivity. Three times wider patent families of the inventions of Uppsala origin characterize actors' market ambition as well as the strength of the University-Industry linkages that are more developed in Uppsala than in Tartu.

\section{Keywords: Intellectual Property (IP), Patenting, Indicators System, University-Industry Collaboration, Knowledge} Production, Invention, Patent Family.

\section{Introduction}

It is generally acknowledged that intellectual property ${ }^{1}$ (IP) created as a result of research and development (R\&D) drives economic growth and welfare in society. The strategies of the European Union, as well as its Member States, originate from this understanding. According to the joint research of the European Patent Office (EPO) and the Office for Harmonization in the Internal Market (OHIM) IPR-intensive industries are shown to have generated almost $26 \%$ of all the jobs and almost $39 \%$ of the total economic activity (GDP - gross domestic product) in the EU during the period 2008-2010 (Wajsman et al., 2013). The capability to create and implement IP is one of the most significant components of the R\&D and innovation system on macro- and micro-level characterizing R\&D activities on state, academia, and business level. The number of scientific publications, PCT patent applications, licence and patent revenues is deemed a primary indicator for Innovation Scoreboard (EU, 2015) aligning states' innovativeness.

Public sector strategy documents, in particular, emphasize the importance of IP statistics as innovation

\footnotetext{
${ }^{1}$ Intellectual property rights can be divided into three main categories: copyright, related rights and industrial property rights. Sometimes copyright and related rights' objects are conceptualized as one category (see, e.g. WIPO, 2016). IP indicators are often confined to registered IP
}

indicator in a socio-economic development context. It is easy enough to count the number of patent applications, patents granted, and scientific publications. This statistical approach, however, does not provide any meaningful insights into the real contribution of IP nor how these welfare goals could be reached. Moreover, for small countries, it raises the question of attribution of R\&D to economic development and international cooperation. In many cases, the results of public (universities') R\&D also enter the public domain that is available to be freely used by anybody anywhere.

Another approach centres on the commercialization of university $R \& D$. It is a widespread practice that universities (not only Estonian) start searching for industrial partners only after a patent application has been filed. Even then they have not conducted any technical or business verification of the patented invention. There is no feasibility study of the economic value of the patent/invention for different markets. The patenting strategy is patterned solely on general recommendations to cover territories of leading countries only. This situation is described by the share of economically meaningful PCT patent applications. In Estonia as well as in Latvia and Lithuania, universities are

objects/rights (see, e.g. WIPO, 2012). Patent statistics is prevailing. Since this is the usual practice, the authors follow the same approach and mention a specific type of IP where necessary. 
the main patent applicants and in the last several years even more than half of the PCT patent applications have belonged to universities. The corresponding number for Sweden and Finland speaks of the opposite trend - their industry amounts to 93-95\% (Table 1), and there is not a single university among the top 10 patent applicants. Of course, the absolute numbers of patenting in the countries differ nearly hundred times. This fact characterizes more the structure and not so much the size of these economies. As known from the knowledge economy approach, Sweden and Finland are the prime examples of innovation-driven economies (Acs, Desai \& Hessels, 2008). Because of their much lower knowledge-base, traditional quantitative IP indicators do not create enough incentives for the Baltic States. The Baltic States, still lagging behind, belong to efficiency-driven economies (Arro et al., 2013). But, they also lack comparative empirical data of knowledge and IP production by R\&D institutions of these country groups.

The aim of the paper is to conceptualize and suggest a strategic indicators system of IP for a small efficiencydriven economy.

To reach the target the following research tasks have been undertaken: (1) discussion of the theoretical framework and the system of IP indicators describing the transition from efficiency-driven to innovation-driven economy, (2) measurement of IP productivity and analysis of constraints in R\&D and knowledge production, and (3) suggestion of IP indicators' system suitable for a small efficiency-driven country.

The theoretical framework of strategic indicators of IP includes qualitative as well quantitative indicators. Qualitative indicators characterize the readiness of universities and other R\&D institutions for knowledge production/transfer and, to some extent, the linkages between academia and industry. Also, these indicators could be implemented as strategic guidance on the level of companies and R\&D institutions as well as for innovativeness on the national level.

Our research methodology includes the analysis of literature and web pages, search in research databases, patent search, and interviews. The empirical research includes a comparison of the productivity of knowledge creation by two universities representing Baltic and Nordic countries: Tartu in Estonia and Uppsala in Sweden. Moreover, the differences in strategic focus of patenting of the results of public R\&D are disclosed.
The main conclusion of the study reveals that in the current development/transition stage pursuing quantitative IP indicators in the public sector is a misleading strategy without qualitative requirements as to the $R \& D$ process. Further policy development should strive for a balance between fundamental and applied research, alignment between R\&D planning, economic feasibility, and IP strategy. The right combination of IP indicators and management framework should be conducive to the process of innovation.

This paper could also be viewed as a conclusion of the IPR work-package of the Research and Innovation Policy Monitoring Programme in Estonia 2011-2015. The principal value of the paper lies in the further development of requirements designed for a small country's IP strategy.

\section{What Makes the Difference between High and Low-Income Countries: Strategic Indicators of Patenting}

Science and industry are deemed to be the attributes of state independence, its cultural and economic sustainability. State economic and welfare development strategy and policy are integrating different societal fields into the whole innovation indicators system (see, e.g. Lundvall, 2007; Freeman, 1995; Vigier, 2007; Daugeliene \& Juocepyte, 2012; Adekola et al., 2008), the same can be said about the regional innovation system (see, i.e. Opekun, 2006). Studies based on the European Regional Innovation Scoreboard (RIS) have demonstrated that the high technology industry has enjoyed $R \& D$ investments and high patenting intensity of the public sector in high-income European countries (Paas \& Vahi, 2012). R\&D expenses and intensity of patenting are much lower in low-income regions inhibiting high-tech production (ibid; see also, e.g., WIPO, 2012, 2015). Lack of the sufficiently qualified labour force and low level of private $R \& D$ investments are the negative factors inhibiting domestic high-tech industry in Estonia and the other Baltic States as well as in other low-income EU countries (Paas \& Vahi, 2012).

The contribution of IP/patenting towards welfare and economic development is different in countries with different income level as established above. Besides the income factor, several other aspects are influencing the linkages between economy and IP (Table 1). These could be the size and structure of the economy, history and political system, education and R\&D system.

Table 1

Patent filing and economic development (selected countries, authors' compilation based on WIPO, 2012, 2015)

\begin{tabular}{|c|c|c|c|c|c|c|c|c|}
\hline \multirow[t]{3}{*}{ State } & \multirow{3}{*}{$\begin{array}{c}\text { Population } \\
2013 \\
\text { Million }\end{array}$} & \multicolumn{3}{|c|}{ GDP, PPP, US\$ (basis 2011) } & \multirow{3}{*}{$\begin{array}{c}\text { Patent filing } \\
2013 \\
\text { Total } \\
\end{array}$} & \multicolumn{3}{|c|}{ PCT patent applications, 2013} \\
\hline & & \multicolumn{2}{|c|}{2013} & \multirow{2}{*}{$\begin{array}{c}1999-2013 \\
\text { Correlation }\end{array}$} & & \multirow[t]{2}{*}{ Total } & \multicolumn{2}{|c|}{ Share in top $10, \%$} \\
\hline & & Per capita & Total, Billion & & & & Industry & University \\
\hline Finland & 5.44 & 37.342 & 203.14 & 0.97 & 12705 & 2095 & 92.9” & $\sim 2.5 ”$ \\
\hline Sweden & 9.59 & 42.167 & 404.38 & 0.87 & 22645 & 3945 & 94.3” & 0 "” \\
\hline Estonia & 1.32 & 24.568 & 32.43 & 0.65 & 273 & 21 & 84.2 & 15.8 \\
\hline Latvia' & 2.01 & 21.488 & 43.19 & 0.53 & 479 & 25 & 15.8 & 76.2 \\
\hline Lithuania' & 2.96 & 23.777 & 70.38 & 0.63 & 220 & 40 & 53.3 & 46.7 \\
\hline Hungary & 9.9 & 22.192 & 219.7 & 0.85 & 1560 & 163 & 58.5 & 41.5 \\
\hline Iceland & 0.32 & 39.906 & 12.77 & 0.85 & 233 & 43 & 100 & 0 \\
\hline Malta' & 0.42 & 28.357 & 11.91 & 0.90 & 273 & 73 & 100 & 0 \\
\hline Malaysia & 29.72 & 22.553 & 670.29 & 0.98 & 2299 & 308 & 13.0 & 24.9 \\
\hline Singapore & 5.4 & 76.226 & 411.62 & 0.99 & 5470 & 838 & 36.6 & 35.8 \\
\hline
\end{tabular}

'Data of GDP and correlation of these countries until 2012; "Share in all PCT patent applications in 2011 
In the (innovation based) knowledge economy (for further discussion on the innovation-based economy, see, e.g., Powell \& Snellman, 2004; Kelli \& Pisuke, 2008), along with domestic patenting, international protection of one's competitive advantage on global markets assumes priority (Hanel, 2006). Therefore, PCT patent applications are just the features to further that aim. A set of countries and indicators found in Table 1 purports to reflect these aspects.

Finland and Sweden are high-income innovation leaders, frequently seen as benchmarks for the Baltic States: Estonia, Latvia and Lithuania. Although the economies of the latter are 3-12 times smaller, and per capita income is approximately twice as low, the number of PCT patent applications in the Baltic States is more than hundred times lower. Among that small number of PCT applications, the share of universities is very high (Table 1), in Estonia, it was even as high as $50 \%$ in 2012. Hungary, which belongs to the same (post-communist) historical and income group as the Baltic States, has a much higher correlation between its GDP and an annual number of patent filings (applications) between 1999 and 2012 (similarly to Sweden and Finland).
In this context, the small economies of Iceland and Malta also follow the pattern of old European countries. Malaysia and Singapore demonstrate that a similar outcome could be reached by countries with very different income level. The governments of these two countries interfere strongly in their economies and innovation process: a substantial share (from 1/3 to 2/3) of applications ranking among the top PCT patent applicants belongs to governmental agencies.

Besides general linkages between patenting activity and GDP, one can conclude from the data (Table 1) that the Baltic States have a great challenge to improve IP and knowledge-base of their welfare.

\section{Quantitative Indicators}

The measurement framework of the Innovation Union Scoreboard (see, e.g., EU, 2015) introduces three types of indicators - Enablers, Firm activities and Outputs consisting of eight innovation dimensions, featuring 25 indicators in total (Figure 1).

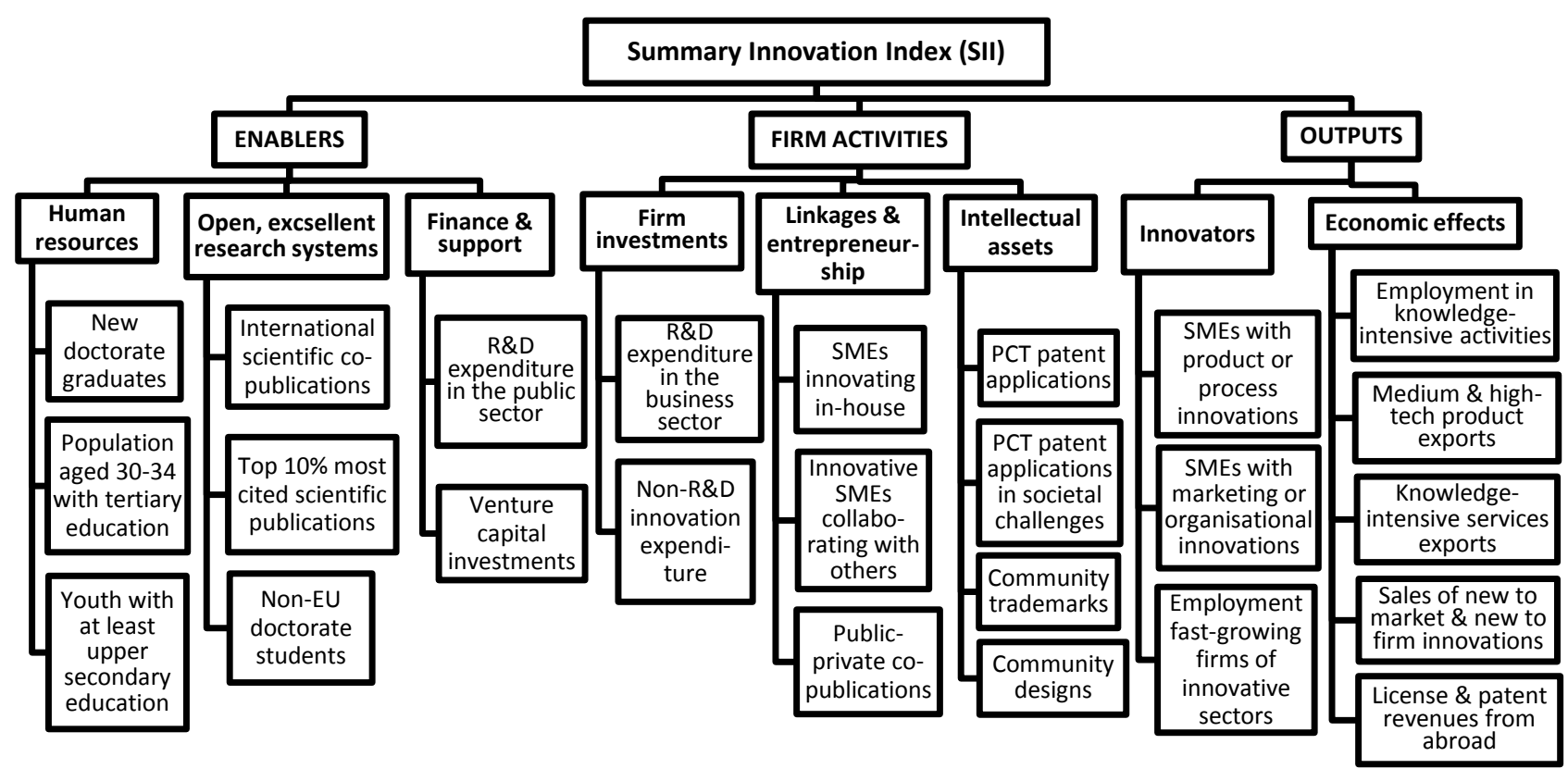

Figure 1. Measurement framework of the Innovation Union Scoreboard (EU, 2015)

The Enablers differentiate between three innovation dimensions external to the firm: Human resources, Open excellent research systems and Finance \& support. Among the eight Enablers' indicators none are directly related to patenting, although two of them - International scientific copublications and $R \& D$ expenditure in the public sector-are referring to the production of new knowledge, i.e. potential IP.

The Firm activities include indirect Firm investments and Linkages \& entrepreneurship as well as direct indicators of Intellectual assets (Figure 1) altogether nine in total. PCT patent applications and PCT patent applications in societal challenges are the direct patenting measures.
Among Outputs, the two dimensions Innovators and Economic effects describe, to some degree, societal as well firm-level impacts of patenting. SMEs with product or process innovation can be, but are not necessarily based on patented technologies. However, License \& patent revenues from abroad exhibit the most direct outcome of patenting.

All the indicators in the scoreboard are measurable. As mentioned above, the econometric measurement of linkages between these indicators and welfare of low-income countries is weak (Paas \& Vahi, 2012). This fact points to the need to look for the causal reasoning of the impact of "input" factors on the output - GDP and welfare. This also means that it is vital to find linkages between knowledge 
creation by public R\&D and economic use of knowledge by firms. Therefore, it is necessary to analyze which indicators motivate which partners in the university-industrygovernment collaboration. For example, as a potential option of IP strategy, usually Public-private co-publications entail lower direct value for the firm, but could be a stronger motivator for the university.

\section{Qualitative Indicators}

Acknowledgement of the fact that low-income countries have less efficient innovation system (for implementing inventions/patents) does not help to solve the problem of how to support the growth of their knowledgebased industries. For improvement, it is imperative to grasp the innovation system linking Enablers and Firm activities for better Outcomes in Fig 1. Therefore, it is crucial to identify the factors that inhibit public and private sector collaboration, frequently called University-IndustryGovernment or Triple-Helix collaboration (Etzkowitz, 2003). This also means understanding barriers on the way from the passive diffusion of knowledge to active engagement in the delivery of economic outcomes by universities from the publicly funded research (Howard, 2005).

The system of IP indicators in Table 2 is a generalization partly drawn from the authors' previous studies (see, e.g., Kelli, Jonsson \& Mets, 2014; Kelli et al., 2013; Mets, Kelli \& Jonsson, 2011; Mets, 2010) and partly the result of literature review (e.g., Mortensen, 2011; Hanel, 2006; Retzig, 2007). There are several strategy models, procedural, operational and regulatory, as well as organisational measures supporting applied orientation of research projects, trust-building and mutual interest for partnership between academia and industry.

Table 2

\section{System of IP indicators*}

\begin{tabular}{|c|c|c|c|}
\hline \multirow{2}{*}{$\begin{array}{l}\text { Indicator } \backslash \\
\text { Institution }\end{array}$} & State & R\&D institution / University & Business / Company \\
\hline & \multicolumn{3}{|c|}{ IP strategy in R\&D strategy framework: } \\
\hline \multirow{5}{*}{ Qualitative } & $\begin{array}{l}\text { Active \& non-linear: the substantial role of } \\
\text { IP (decisive in some sectors) in S\&T } \\
\text { strategy design, planning and funding } \\
\text { decisions and supporting collaborative } \\
\text { research. } \\
\text { Passive \& linear: IP is the (monitored) } \\
\text { outcome of S\&T }\end{array}$ & $\begin{array}{l}\text { Active non-linear: the substantial role of IP } \\
\text { (decisive in some sectors) in R\&D strategy, } \\
\text { planning and funding decisions and } \\
\text { collaborative research. } \\
\text { Passive \& linear: IP is the monitored } \\
\text { outcome of R\&D, linear commercialization } \\
\text { strategy }\end{array}$ & $\begin{array}{l}\text { Strategy of patent portfolio } \\
\text { Active: the substantial role of IP } \\
\text { (decisive in some sectors) in R\&D } \\
\text { partnership strategy, and funding } \\
\text { decisions and collaborative research. } \\
\text { Passive: IP is the occasional } \\
\text { outcome of R\&D }\end{array}$ \\
\hline & \multicolumn{3}{|c|}{ Operational / Procedural } \\
\hline & $\begin{array}{l}\text { Regular sector science and technology } \\
\text { (S\&T) and IP evaluation / audit, and } \\
\text { prognosis, including due diligence and } \\
\text { feasibility study for research programs and } \\
\text { industry sector }\end{array}$ & $\begin{array}{l}\text { Regular sector R\&D and IP value } \\
\text { assessment / audit, and prognosis, including } \\
\text { due diligence and feasibility study for } \\
\text { research projects, patent applications and } \\
\text { industrial partnership. } \\
\text { Scoring inventions/patents }\end{array}$ & $\begin{array}{l}\text { Regular R\&D and IP monitoring, } \\
\text { portfolio evaluation / audit and } \\
\text { prognosis (feasibility study). } \\
\text { Scoring inventions/patents }\end{array}$ \\
\hline & \multicolumn{3}{|c|}{ Organisational } \\
\hline & $\begin{array}{l}\text { Ecosystem: Support measures (state order) } \\
\text { for IP-based knowledge transfer and spin- } \\
\text { off programs. IPR support for SMEs }\end{array}$ & $\begin{array}{l}\text { IP-based knowledge transfer infrastructure } \\
\text { and program, including international and } \\
\text { domestic Spin-off program }\end{array}$ & $\begin{array}{l}\text { IPR unit } \\
\text { Linkages to IPR services (incl. } \\
\text { SMEs) }\end{array}$ \\
\hline \multirow{7}{*}{ Quantitative } & $\begin{array}{l}\text { Share of knowledge assets in GDP, } \\
\text { including sectoral, } €, \%\end{array}$ & $\begin{array}{l}\text { Patent portfolio (incl. know-how), other IP, } \\
\text { value, by sector, } €\end{array}$ & $\begin{array}{l}\text { Share of knowledge assets in firm's } \\
\text { value, } \%, €\end{array}$ \\
\hline & $\begin{array}{l}\text { Collaborative S\&T programs, firms' } \\
\text { contribution, } \%, €\end{array}$ & $\begin{array}{l}\text { Share of collaborative R\&D, firm's } \\
\text { contribution, } \%, €\end{array}$ & $\begin{array}{l}\text { Collaborative and internal R\&D, \%, } \\
€\end{array}$ \\
\hline & Co-publications, $\%, \mathrm{~N}$ & Co-publications, $\%, \mathrm{~N}$ & Co-publications, $\%, \mathrm{~N}$ \\
\hline & Patent portfolio, patents (families), $\mathrm{N}$ & Patent portfolio (families), $€, \%, \mathrm{~N}$ & Patent portfolio, $\mathrm{N}, €$ \\
\hline & Licences (share of patents), $€$ & Licences, IP sales (share of patents), $€$ & $\begin{array}{l}\text { Licences, IP sales (share of patents), } \\
€\end{array}$ \\
\hline & Support to technology start-ups, $€$ & $\begin{array}{l}\text { Idea disclosures (incl. accepted), N; spin- } \\
\text { offs }\end{array}$ & Idea disclosures (incl. accepted), $\mathrm{N}$ \\
\hline & $\begin{array}{l}\text { Patentometrics (general), S\&T level, } \\
\text { internationalisation, co-inventions }\end{array}$ & $\begin{array}{l}\text { Patentometrics (general), R\&D strategy, } \\
\text { internationalisation, co-inventions }\end{array}$ & $\begin{array}{l}\text { Corporate strategy, technology } \\
\text { diffusion, Patent citation }\end{array}$ \\
\hline
\end{tabular}

*Authors' compilation and synthesis based on: Arundel, Es-Sadki, Barjak et al., 2013; Mortensen, 2011; Kelli, Jonsson, Mets, 2014; Kelli, Mets, Jonsson et al., 2013; EPO, 2010; Ismail, Mason, Cooper \& Omar, 2008; Venkataraman, 2004; Isenberg, 2010.

Among them is the Active non-linear vs. Passive linear IP strategy, which describes the means how universities try to commercialize their $\mathrm{R} \& \mathrm{D}$ results. According to the passive linear model, a university starts searching for an industrial partner only after an accidental invention and filing of a patent application as the result of the research project. A more viable strategy would be to establish collaboration or/and conduct a spin-off feasibility study already in the planning phase before the launch of the research project. It could be a way to prepare patenting strategy as well (Arundel, Es-Sadki, Barjak et al., 2013; Arundel \& Patel, 2003).
A central part of this approach could be the reorientation from IP profit (earning income) to innovation support by universities (Kelli et al., 2013) which includes "soft measures" for networking with firms in collaborative platforms such as AIMday®. AIMday ${ }^{\circledR}$ (AcademiaIndustry Meeting day) is a unique special collaboration platform that includes a preparatory phase where the collaboration scope is defined, meetings and other elements for the academia-industry interaction developed at the Uppsala University (Jonsson et al., 2015).

Of course, the qualitative measures described above could be presented in part by using quantitative indicators, 
like the funds (e.g., \% of knowledge transfer budget) allocated for such purposes. But more important are the goals and quality of such measures.

\section{Multilevel IP Indicators' System for Transition}

The theoretical framework of strategic indicators of IP system includes qualitative as well as quantitative indicators. Qualitative indicators characterize the readiness and capacity of universities and other R\&D institutions for knowledge production/transfer and the possible linkages between academia and industry. Furthermore, these indicators could be implemented as strategic guidance on the level of companies and R\&D institutions as well as for innovativeness on the state level.

The system (Table 2) includes qualitative, and quantitative indicators applied at the state as well as university and company level. These indicators are not proposed to replace the Scoreboard, but complement existing framework of bibliometrics and patentometrics. The table presents general fields and measures rather than very concrete details of the IP system and strategy for a small country, e.g. Estonia.

Subject to the conclusions of the Innovation Scoreboard (Figure 1) and IP indicators (Table 2), the role of the state is in part the development and support of the general ecosystem of Enablers including the wider framework not present in Figure 1. This framework has been described as a model for how partners of the Triple Helix network could collaborate (see, e.g. Mets 2010). It follows from this general understanding that patenting of domestic inventions is only one indication of the movement towards the knowledge-based economy. Therefore, qualitative measures on the state level are targeted at universityindustry collaboration. It is particularly important to reach "soft measures" like trust-building AIMday ${ }^{\circledR}$ type collaborative platforms. In other words, within the systemic approach technology innovation is tightly linked to social innovations, and social "soft" measures should precede technology knowledge transfer. This is the basis for transition to active IP strategy at all institutional levels.

The active IP and innovation strategy also means implementation of pro-active IP evaluation procedures and decision-making for R\&D policy shaping and funding. After creating organisational infrastructure, quantitative IP indicators could attain the real meaning they have in the Scoreboard (see Table 2). That is the logic to follow by small transition countries.

\section{Empirical Study}

As already mentioned above, $\mathrm{R} \& \mathrm{D}$ and knowledge intensity of Estonian as well as the other Baltic States' companies is low comparing their Nordic counterparts. Although Innovation Scoreboard data is available and several studies have researched patenting and IP protection (e.g., Mets, 2010; Paas \& Vahi, 2012), we still lack the understanding of "bottle-necks" on the way to better use of knowledge production in these countries. As part of the Research and Innovation Policy Monitoring Programme, this empirical study focuses on the implementation of bibliometrics' and patentometrics' data for comparison of knowledge production and patenting behaviour among Estonian and Swedish academics. To this end, the continuation of prior studies based on Tartu and Uppsala universities offers an excellent opportunity.

According to the Scoreboard, Uppsala University is the embodiment of a highly innovative country: Sweden (EU, 2015). It is a suitable benchmark for the institutional level but also provides information about the national policy. Both are old classical universities and belong to the Coimbra Group of European multidisciplinary universities of high international standard (http://www.coimbra-group.be/ index. html).

The survey had the following aims: (1) comparison of science and technology (S\&T) knowledge production by academics, (2) mapping patenting practice among the personnel of these two universities.

Knowledge production was measured by collecting data in two ways: (a) search for science and technology publication by academicians in the Web of Knowledge where the university affiliation was shown, (b) search for patent applications in esp@ cenet databases.

First, the patent applications with the university as the applicant were examined. Subsequently, the applications involving certain persons were identified. During this process, patent family information was mapped (Kim \& Lee, 2015). A personalised search was necessary for the personnel of the Uppsala University because of the "professor's privilege". Professor's privilege (also the exemption for teachers) is a concept in Sweden, which attributes the ownership of research results (inventions) to academic personnel (see, e.g., Geuna \& Messi, 2011). They are free to decide on the best possible method of IP protection.

The search was carried out in 2013-2014. As widely known, the publication period of a patent application can be even longer than that of academic papers in certain peerreviewed journals (extending to some years). Therefore, the survey period is limited to the years 2000-2010. Patent families were also analyzed to explain the geographical range of patent protection.

It was rather complicated to identify faculty members in the list of inventors even when using personalised search. There were issues concerning differentiation of namesakes among the Swedish inventors. As in the former study (Mets, 2010), the analysis of academic profile and residence of the inventor was used. However, it goes without saying that the data gathered in such a manner cannot be deemed fully accurate.

It should be mentioned here that the data for the Uppsala University academic personnel was collected as the result of the personalised search. The same method was used for Tartu after searching for the university as a patent applicant. The results (below) were somewhat surprising as Tartu University has the institutional ownership regime which means that the research results created by academic personnel belong to the university.

\section{Knowledge Production by Two Universities}

As mentioned in the earlier studies (Mets, 2010), publication activity of researchers from Uppsala according to the Web of Science is approximately 1.5 times higher than 
that of their colleagues in Tartu. (This number does not take into account the structure of disciplines in the universities.) The figures (Table 3, Figure 2) for publications production and productivity of patented IP by members of the two universities demonstrate equal indicator levels.

However, the first assessment after the institutional patent search showed drastic differences (3X). This is a sign that Estonian researchers are by no means less active inventors than their colleagues from Uppsala in Sweden. This fact indicates rather that university invention/patent ownership as a part of employment regulation is not efficient in the Estonian university.

Patent applications by personnel of Uppsala University and the University of Tartu, and the institutional patent applications of the University of Tartu (TU) by patent families and classes

\begin{tabular}{|c|c|c|c|c|c|c|c|c|c|c|c|c|c|}
\hline \multirow{12}{*}{$\begin{array}{l}\mathbf{U} \\
\mathbf{p} \\
\mathbf{p} \\
\mathbf{s} \\
\mathbf{a} \\
\mathbf{l} \\
\mathbf{a}\end{array}$} & \begin{tabular}{|l|} 
Class \\
\end{tabular} & 2000 & 2001 & 2002 & 2003 & 2004 & 2005 & 2006 & 2007 & 2008 & 2009 & 2010 & Total \\
\hline & A & 12 & 11 & 20 & 24 & 11 & 7 & 20 & 16 & 16 & 17 & 15 & 169 \\
\hline & $\mathrm{B}$ & 6 & 4 & 10 & 8 & 7 & 12 & 2 & 11 & 8 & 4 & 9 & 81 \\
\hline & $\mathrm{C}$ & 17 & 14 & 13 & 10 & 6 & 9 & 7 & 17 & 7 & 9 & 7 & 116 \\
\hline & $E$ & 0 & 0 & 0 & 0 & 0 & 0 & 0 & 0 & 1 & 2 & 0 & 3 \\
\hline & $\mathrm{F}$ & 0 & 1 & 3 & 3 & 1 & 1 & 1 & 5 & 6 & 4 & 2 & 27 \\
\hline & $\mathrm{G}$ & 5 & 1 & 8 & 18 & 4 & 6 & 15 & 9 & 6 & 3 & 3 & 78 \\
\hline & $\mathrm{H}$ & 8 & 10 & 4 & 10 & 2 & 7 & 11 & 5 & 4 & 7 & 4 & 72 \\
\hline & $\mathrm{Y}$ & 0 & 0 & 0 & 0 & 0 & 0 & 0 & 0 & 4 & 0 & 0 & 4 \\
\hline & \begin{tabular}{|l|} 
Total \\
\end{tabular} & 48 & 41 & 58 & 73 & 31 & 42 & 56 & 63 & 52 & 46 & 40 & 550 \\
\hline & Sc\&Techn & 2167 & 2226 & 2215 & 2202 & 2241 & 2358 & 2557 & 2550 & 2581 & 2770 & 3014 & 26881 \\
\hline & \begin{tabular}{|l|} 
Pat/articles \\
\end{tabular} & 2.2 & 1.8 & 2.6 & 3.3 & 1.4 & 1.8 & 2.2 & 2.5 & 2.0 & 1.7 & 1.3 & 2.0 \\
\hline \multirow{11}{*}{$\begin{array}{l}\mathbf{T} \\
\mathbf{a} \\
\mathbf{r} \\
\mathbf{t} \\
\mathbf{u}\end{array}$} & \begin{tabular}{|l|} 
Pat/articles \\
\end{tabular} & 1.3 & 2.6 & 0.6 & 1.4 & 0.5 & 1.4 & 2.6 & 3.4 & 2.2 & 2.0 & 2.5 & 2.0 \\
\hline & Sc\&Techn & 307 & 352 & 324 & 346 & 426 & 442 & 470 & 584 & 548 & 613 & 720 & 5132 \\
\hline & \begin{tabular}{|l|} 
Total \\
\end{tabular} & 4 & 9 & 2 & 5 & 2 & 6 & 12 & 20 & 12 & 12 & 18 & 102 \\
\hline & $\mathrm{A}$ & 0 & 2 & 0 & 3 & 0 & 1 & 4 & 3 & 6 & 2 & 5 & 26 \\
\hline & $\mathrm{B}$ & 1 & 0 & 0 & 1 & 1 & 1 & 2 & 1 & 2 & 2 & 1 & 12 \\
\hline & $\mathrm{C}$ & 2 & 5 & 2 & 1 & 1 & 3 & 3 & 10 & 3 & 5 & 8 & 43 \\
\hline & $\mathrm{D}$ & 0 & 1 & 0 & 0 & 0 & 0 & 0 & 0 & 0 & 0 & 0 & 1 \\
\hline & $\mathrm{F}$ & 0 & 0 & 0 & 0 & 0 & 0 & 1 & 0 & 1 & 1 & 0 & 3 \\
\hline & G & 0 & 0 & 0 & 0 & 0 & 1 & 0 & 3 & 0 & 2 & 0 & 6 \\
\hline & $\mathrm{H}$ & 1 & 1 & 0 & 0 & 0 & 0 & 2 & 1 & 0 & 0 & 4 & 9 \\
\hline & $\mathrm{Y}$ & 0 & 0 & 0 & 0 & 0 & 0 & 0 & 2 & 0 & 0 & 0 & 2 \\
\hline $\mathbf{T}$ & Total & 1 & 1 & 2 & 2 & $\mathbf{0}$ & 2 & 1 & 2 & 11 & 7 & 5 & 34 \\
\hline $\mathbf{U}$ & Pat/articles & 0.3 & 0.3 & 0.6 & 0.6 & 0.0 & 0.5 & 0.2 & 0.3 & 2.0 & 1.1 & 0.7 & 0.7 \\
\hline
\end{tabular}

Pat/articles - number of patent applications per $100 \mathrm{Web}$ of Science articles

These findings indicate even more - scholars of the University of Tartu are no less patent application-oriented than their Swedish counterparts. Because of the "professor's privilege" Swedish academic inventors must be more aware of and active in patenting than Estonians. This is also evident from the scale of protection (Table 4).

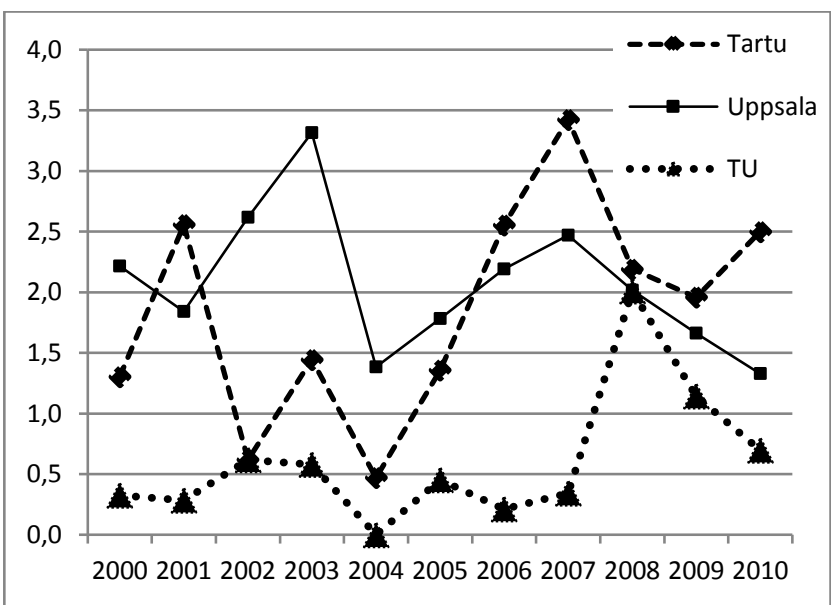

Figure 2. Number of patent applications per 100 articles of the Web of Science by the personnel of the University of Tartu and

Uppsala University, the same (TU) for institutional patent applications of the University of Tartu
The Estonian data (Table 3) shows that approximately $70 \%$ of academic patents of Estonians may be filed by industrial applicants in line with the general practice in Europe (Bacchiocchi \& Montobbio, 2009). Which industrial relations could be behind that phenomenon, this is the subject of further studies.

Although the two types (publications and patent applications) of productivity of academic staff from two universities correspond very closely to one another, then the patenting behaviour still differs. The patent families of Swedish applicants are much wider than those of Estonian academic inventors (Table 4).

Table 4

Sizes of academic patent families of two universities by classes, filings 2000-2010

\begin{tabular}{|c|c|c|}
\hline Class & Uppsala & Tartu \\
\hline A & 10.7 & 4.3 \\
\hline B & 6.4 & 2.7 \\
\hline C & 7.1 & 4.8 \\
\hline E & 2.3 & 2.0 \\
\hline F & 9.4 & 3.3 \\
\hline G & 4.0 & 2.4 \\
\hline H & 16.6 & 6.1 \\
\hline Y & 1 & 1 \\
\hline
\end{tabular}

The patent families of the inventors of Uppsala University are almost three times wider than of inventors of the University of Tartu. This characterizes actors' market ambition as well as resources available for patenting. But 
patent family size is also an indicator of the value of the invention protected by the patent (Sapsalis, Van Pottelsberghe de la Potterie \& Navon, 2006; Hanel, 2006). This seems to suggest that the inventions of Swedish academics are more valuable than those of their Estonian counterparts.

\section{Discussion and Conclusions}

Intellectual property indicators are still measured in terms of registered property rights (industrial property). Patenting is a central indicator of new knowledge production. Using only registered IPR, especially in a small (innovation-oriented) transition country, is not informative for strategy purposes and does not create adequate incentives. A formal approach based only on statistics (e.g., Khayyat \& Lee, 2015) or on Innovation Scoreboard can result in a distorted picture of the real situation.

Estonia as a country in transition from efficiency to innovation-driven economy is characterized by a modest level of $R \& D$ expenses and low patenting activity in the private sector. This means that the importance of registered IP as the innovation indicator is limited and formal figures only partly characterize innovation capabilities. Irrespective of the differences in IP ownership regulations between universities of Tartu and Uppsala revealed by the data it may be concluded that the patenting intensity of the personnel of the Estonian university is comparable to their Swedish colleagues. This is an indication that productivity of knowledge and IP on a personal level can be similar in the universities of Estonia and Sweden. Backwardness appears primarily in the international scope of patenting that can refer to the lower value of patents as well as the constraints in university-industry collaboration. In this context, knowledge and IP productivity, and the extent of patent families could be indicators to account for strategy evaluation. Therefore, strategy models and qualitative behavioural patterns of benchmark countries are the best starting point for building up one's IP indicators' system.

One of the challenges in creating an IP monitoring system is finding a balance between simplicity and reliability. Evaluation of the university-industry collaboration should not be limited to direct commercialization or knowledge (IP) transfer indicators (IP licensing, sales, spin-offs). Classical patent application and registration and licensing data are used on the primary level. On the advanced level, the characteristics influencing IP value and economic impact are taken well into account. Real (not formal) collaboration between academia and firms as a form of indirect commercialization should be the true measure instead. In the Estonian and other Baltic countries' context it means implementation of a combination of direct and indirect knowledge transfer and relevant indicators. At the same time, over-complicated systems should be avoided. Only this allows comparability with other countries.

From the discussion above the authors have reached the following logic for shaping the IP strategy and indicators system within a small efficiency-driven economy country: (1) implementation of active non-linear IP strategy on state, R\&D institutions' and companies' level evaluating the IP framework qualitatively (qualitative indicators); (2) widening the list of quantitative IP indicators supporting follow-up of qualitative results. Of course, the role of IPstrategy remains as the principal part of $R \& D$ and innovation strategy.

It is reasonable to prioritize qualitative patenting and IP related indicators mapping strategies and concrete activities supporting university-industry collaboration. Universityindustry collaborative patenting rightfully belongs to this group. Figures measuring collaboration with industry should be preferred. The role of IP indicators in the innovation system should be seen as tracking linkages with economic development. Patenting figures as a strategic aim should be avoided until reaching the qualitative targets.

The correlation between patent filing and GDP is higher in bigger economies and higher income countries. The share of university patents is lower in bigger economies, countries with higher income and lower interference by governments. Careful government interference can prove to be an instrument for innovation support. The guidelines in that process, especially at the initial stage, cannot be limited to the mere quantitative indicators prescribed by innovation leaders. More important is to follow qualitative patterns of pathways contributing to innovation-based economic development. Even replication of such methods does not suffice. New innovative measures are urgently needed in innovation development.

\section{Acknowledgement}

This publication has been supported by the European Social Foundation through the Research and Innovation Policy Monitoring Programme.

\section{References}

Acs, Z. J., Desai, S., \& Hessels, J. (2008). Entrepreneurship, economic development and institutions. Small Business Economics, 31, 219-234. http://dx.doi.org/10.1007/s11187-008-9135-9

Adekola, A., Korsakiene, R., \& Tvaronaviciene, M. (2008). Approach to innovative activities by Lithuanian companies in the current conditions of development. Ukio Technologinis ir Ekonominis Vystymas, 14(4), 595-611, doi: 10.3846/1392-8619.2008.14.595-611.

Arro, T., Elenurm, T., Kuttim, M., Liigus, E., Masso, J., Mets, T., Paes, K., Raudsaar, M., Rebane, K., Reino, A., \& Poder, K. (2013). Globaalne ettevotlusmonitooring 2012: Eesti raport. Eesti Arengufond, Tallinn.

Arundel, A., Es-Sadki, N., Barjak, F. et al. (2013). Knowledge Transfer Study 2010-2012. Final Report. European Commission.

Arundel, A., \& Patel, P. (2003). Strategic patenting. Background report for the Trend Chart Policy Benchmarking Workshop "New Trends in IPR Policy", Luxembourg, 3-4 June. 
Bacchiocchi, E. \& Montobbio, F. (2009). Knowledge diffusion from university and public research. A comparison between US, Japan and Europe using patent citations. Journal of Technology Transfer, 34, $169-181$. http://dx.doi.org/10.1007/s10961-007-9070-y

Daugeliene, R., \& Juocepyte, S. (2012). The Evolvent of Criteria for Assessment of Innovation Expression in the State Level. Inzinerine Ekonomika-Engineering Economics, 23(2), 154-162. http://dx.doi.org/10.5755/j01.ee.23.2.1540

EPO (European Patent Office). (2010). Patent portfolio management with IPscore 2.2. Available from the Internet: https://www.epo.org/searching/free/ipscore.html.

Etzkowitz, H. (2003). Innovation in innovation: the Triple Helix of university-industry-government relations. Social Science Information, 42(3), 293-337. http://dx.doi.org/10.1177/05390184030423002

EU (European Union). (2015). Innovation Union Scoreboard. European Commission. Available from the Internet: http://ec.europa.eu/growth/industry/innovation/facts-figures/scoreboards/files/ius-2015_en.pdf.

Freeman, C. (1995). The national system of innovation in historical perspective. Cambridge Journal of Economics, 19(1), $5-24$.

Geuna, A. \& Messi, F. (2011). Changes to university IPR regulations in Europe and the impact on academic patenting. Research Policy, 40, 1068-1076, DOI:10.1016/j.respol.2011.05.008.

Hanel, P. (2006). Intellectual property rights business management practices: A survey of the literature. Technovation, 26, 895-931, doi:10.1016/j.technovation.2005.12.001.

Howard, J. (2005). The emerging business of knowledge transfer: From diffusion to engagement in the delivery of economic outcomes from publicly funded research. Triple helix 5, The capitalization of knowledge, Turin, Italy.

Isenberg, D. J. (2010). How to Start an Entrepreneurial Revolution. Harvard Business Review, June, 41-50.

Ismail, K., Mason, C., Cooper, S., Omar, W. Z. W., \& Majid, I.A. (2008). A Need for Due Diligence Systems in Commercialization Process of University. - N.A. Talib, A.A. Senin (Ed.), Technology management: theory and practice, (pp. 111-155). Skudai: Universiti Teknologi Malaysia.

Jonsson, L., Baraldi, E., Larsson, L.-E., Forsberg, P., Severinsson, K. (2015). Targeting Academic Engagement in Open Innovation: Tools, Effects and Challenges for University Management. Journal of Knowledge Economy, 6(3), 522550. http://dx.doi.org/10.1007/s13132-015-0254-7

Kelli, A., Jonsson, L., \& Mets, T. (2014). Management of Intellectual Property Rights at Academia: the Estonian and Swedish Perspective. International Journal of Technology Management \& Sustainable Development, 13(3), $219-236$. http://dx.doi.org/10.1386/tmsd.13.3.219_1

Kelli, A., Mets, T., Jonsson, L., Pisuke, H. \& Adamsoo, R. (2013). The changing approach in Academia-Industry collaboration: From profit orientation to innovation support. TRAMES. A Journal of the Humanities and Social Sciences, 17(67/62), 3, 215-241. http://dx.doi.org/10.3176/tr.2013.3.02

Kelli, A., \& Pisuke, H. (2008). Intellectual Property in an Innovation-based Economy. Review of Central and East European Law, 33 (2), 223-238. http://dx.doi.org/10.1163/092598808X262614

Khayyat, N. T., \& Lee, J. D. (2015). A measure of technological capabilities for developing countries. Technological Forecasting \& Social Change, 92, 210-223, doi:10.1016/j.techfore.2014.09.003.

Kim, J., \& Lee, S. (2015). Patent databases for innovation studies: A comparative analysis of USPTO, EPO, JPO and KIPO. Technological Forecasting \& Social Change, 92, 332-345, doi:10.1016/j.techfore.2015.01.009.

Lundvall, B. A. (2007). National Innovation Systems - Analytical Concept and Development Tool. Industry and Innovation, 14(1), 95-119, DOI: 10.1080/13662710601130863.

Mets, T., Kelli, A., \& Jonsson, L. (2011). Two universities, two patent ownership regimes: what is the difference for knowledge transfer? - Social Research, 3(24), 67-79.

Mets, T. (2010). Entrepreneurial Business Model for Classical Research University. Inzinerine Ekonomika-Engineering Economics, 21(1), 80-89.

Mortensen, P. S. (2011). Patentometrics as Performance Indicators for Allocating Research Funding to Universities. CFA Working Paper 2011/1. The Danish Centre for Studies in Research and Research Policy, School of Business and Social Sciences, University of Aarhus.

Opekun, E. (2006). Development of the Innovation System in Grodno Region: Condition, Problems, Prospects. Engineering Economics, 5(50), 80-85.

Paas, T., \& Vahi T. (2012). Economic growth, convergence and innovation in the EU regions. Discussions on Estonian Economic Policy, 20(1), 105-121.

Powell, W. W., \& Snellman, K. (2004). The Knowledge Economy. Annual Review of Sociology, 30, 199-220, doi: 10.1146/annurev.soc.29.010202.100037.

Reitzig, M. (2007). How executives can enhance IP strategy and performance. MIT Sloan Management Review, Fall, 3743. 
Sapsalis, E., Van Pottelsberghe de la Potterie, B., \& Navon, R. (2006). Academic versus industry patenting: An in-depth analysis of what determines patent value. Research Policy, 35.10, 1631-1645. http://dx.doi.org/10.1016/j.respol.2006.09.014

Venkataraman, S. (2004). Regional transformation through technical entrepreneurship. Journal of Business Venturing, 19, 153-167. http://dx.doi.org/10.1016/j.jbusvent.2003.04.001

Vigier, P. (2007). Towards a citizen-driven innovation system in Europe. Innovation: The European Journal of Social Science Research, 20(3), 191-202. http://dx.doi.org/10.1080/13511610701707359

Wajsman, N., Thumm, N., Kazimierczak, M., et al. (2013). Intellectual property rights intensive industries: contribution to economic performance and employment in the European Union Industry-Level Analysis Report, September 2013. A joint project between the European Patent Office and the Office for Harmonization in the Internal Market. EPO \& OHIM.

WIPO (2012). World Intellectual Property Indicators. Geneva: World Intellectual Property Organization.

WIPO (2016). What is Intellectual Property? WIPO Publication No. 450(E). Geneva: World Intellectual Property Organization. Available from the Internet: http://www.wipo.int/edocs/pubdocs/en/intproperty/450/wipo_pub_450.pdf.

WIPO (2015). Statistical Country Profiles. Geneva: World Intellectual Property Organization. Available from the Internet: http://www.wipo.int/ipstats/en/statistics/country_profile/\#S.

The article has been reviewed.

Received in December, 2015; accepted in June, 2016. 